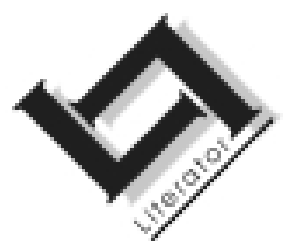

\title{
The top, the bottom and the middle: Space, class and gender in Metropolis
}

\author{
Deirdre C. Byrne \\ Department of English \\ University of South Africa \\ PRETORIA \\ E-mail: byrnedc@unisa.ac.za
}

\section{Abstract}

The top, the bottom and the middle: Space, class and gender in Metropolis

My article explores the images and metaphors relating to space in Fritz Lang's 1926 film, Metropolis (remade in 1984 by Georgio Moroder). Using a primarily Marxist interpretive framework, I analyse the spatial layout of the filmic city of Metropolis, divided into three levels, one above ground and two underground, as metonymic of the class divisions in the urban society that are represented in the film. The article also examines the architecture of Metropolis as representing social values and conflicts. It then proceeds to investigate the film's gender dynamics as revealed in the two figures of the robot Maria and the real Maria, and concludes that the film's gender and class ideology is remarkably conservative.

\section{Opsomming}

Bo, onder en in die middel: ruimte, klasverdeling en gender in Metropolis

My artikel ontleed die beelde en metafore van die leefruimtes in Fritz Lang se 1926-film, Metropolis (weer verfilm in 1984 deur Georgio Moroder). Binne 'n hoofsaaklik Marxistiese interpretasieraamwerk ontleed ek die ruimtelike uitleg van die filmstad Metropolis, wat onderverdeel is in drie vlakke, een bokant die grond en twee ondergronds, en vertolk dit as metonimies van die klasverdeling in die stedelike samelewing wat in die film uitgebeeld word. Die artikel ontleed ook die argitektuur van Metropolis as verteenwoordigend van sosiale waardes en konflikte. Vervolgens ontleed ek die film se genderdinamika soos dit uitgebeeld word in die twee figure van die robot-Maria en die werklike Maria, en kom tot die gevolgtrekking dat die film se gender- en klasideologie verbasend konserwatief is. 


\section{Approach and methodology}

My article explores spatial metaphors in the representation of class and gender conflicts in Georgio Moroder's 1984 reconstruction of Fritz Lang's 1926 film, Metropolis. My approach draws primarily on Marxist cultural criticism in reading Metropolis, but also refers to Christian symbolism and current gender theory. I do not wish to put forward a Marxist critical analysis of the film as the only way to read it: rather, I believe the spatial imagery in Metropolis uses the generic resources of science fiction to articulate a Marxist analysis of urban topography and society in the capitalist industrial era. Darko Suvin famously describes science fiction's "two main species or models, the extrapolative and the analogical one" (Suvin, 1979:27). He goes on to define extrapolative science fiction as "based on direct, temporal extrapolation [that is, of current social and historical trends] and centered on sociological (that is, utopian and antiutopian) modeling" (Suvin, 1979:27), while analogical science fiction may not project into the future, but imagines a contemporaneous analogy of the author's empirical reality. In terms of Suvin's taxonomy, Metropolis is an example of extrapolative science fiction, using the device of antiutopian or dystopian projection of experienced conditions into an imagined future. In Kathryn Hume's words, as "literature of vision" (Hume, 1984:82), science fiction provides a means for human beings to reflect on "the ways in which we find ourselves and lose ourselves as human beings" (Bourbon, 1999:190). The characters in Metropolis, trapped within a system of economic stratification, do indeed, as Marx argues, "lose themselves" within class-based alienation.

For the purposes of my article, Metropolis is, as the title indicates, a filmic portrayal of a city; the social relations that it contains are represented in its architecture and layout. My reading thus stands in contrast to other possible readings, which might see the film as the narrative of Freder Fredersen's search for his true love or an adult relationship with his father. I do not deny that character development is essential to the film's plot, but my focus is on the interaction of conflicting classes and on Freder, his father Joh and Maria as representatives of those groups and the ideological forces that they embody.

\section{Space/s and architecture in Metropolis}

The eponymous Metropolis is a large urban construction on three levels. At the top, spatially and financially - that is, above ground - is the level of the capitalist bourgeoisie. Initially this domain is portrayed as preindustrial and almost pastoral. The visual images show young people enjoying their physicality, indulging in races and games reminiscent of the Roman circus. In later scenes it becomes apparent that the upper 
level also contains other diversions, notably those of sex in the Gardens of Earthly Delight and in Yoshiwara's den of vice, and that its layout is typically industrial. Metropolis's architecture and road plan layout centre around an enormous dome-shaped construction. Anachronistically, this building reminds the twentieth-century viewer of the imposing, symmetrical, Victorian-style skyscrapers that are the trademark of Manhattan. One of these, the Chrysler building, is especially reminiscent in style and ideology of the architecture of Metropolis. The very name of the Chrysler building, like the shape of Metropolis's central building, testifies vividly to the dominance of capital over labour and articulates the power of the moneyed classes to shape landscape and social spaces. Those in possession of economic power can not only shape, but also name, the products their capital generates: thus the Chrysler building commemmorates a company, and the name "Metropolis" marks the city as a microcosm of a general stratification of society along economic lines.

The vertical lines of the building at the city's centre demonstrates a desire to soar above the earth, above human limitations and conditions a desire that can only be achieved at the expense of workers to construct and maintain the edifices. As Yi-fu Tuan (1974:28), among other theorists, notes:

The vertical versus the horizontal dimension ... [embodies] the antithesis between transcendence and immanence, between the ideal of disembodied consciousness (a skyward spirituality) and the ideal of earth-bound identification. Vertical elements in the landscape evoke a sense of striving, a defiance of gravity.

The still from Metropolis entitled "The classic view of the city" shows its dominant edifice as a skyward-reaching building, whose domed upper section again recalls the Chrysler. According to Tuan this architectural design combines the circle as "a two-dimensional translation of heaven to earth" with the transcendence of verticality. The architectural spikes that protrude from the building demonstrate its hostility towards contending forces and capital's ability to repel all assaults.

The visual impact of above-ground Metropolis is strongly futuristic (the film is set in 2026), allowing critics to categorize the film as science fiction with allegorical overtones. The allegory inheres in the similarities between the city's structure and the Christian division of cosmic space into Heaven and Hell. When read from this perspective, above-ground urban Metropolis emerges as an analogue for Heaven (with the capitalists enjoying all the benefits that money can buy, including orderly, spacious and aesthetically-designed interiors) while the subterranean 
levels appear as a vision of Hell, complete with infernal monsters whose appetite for live human beings is insatiable. ${ }^{1}$ Looking out from his office window, Joh Fredersen (the "Master of Metropolis") sees a vision of multi-layered urban space, with aerial walkways, bright lights and a high pedestrian traffic flow, that is common in late twentieth-century filmic representations of cities. These images are similar to those used in much later science-fiction films, such as Dark city (1998) and The fifth element (1997). In the futuristic visual imagery that creates Metropolis on screen, Lang extrapolates from the conditions of class conflict in his own era to suggest that class division exerts a ubiquitous influence on the urban distribution of space. As I shall argue, he provides a partial solution for the problem of conflict between privileged and disempowered classes at the film's close, but this solution remains problematic in terms of class and especially in terms of gender.

The middle level of the city is occupied by the machines that power above-ground Metropolis. These are enormous and intricate mechanical constructions, ensuring that the labour that powers and maintains the city is largely mechanized. The representation of these machines constitutes the film's "novum" (Suvin, 1979:4), the element that Suvin identifies as constitutive of science fiction. In Broderick's terms, they provide the foundation for designating Metropolis as an other-world tale where "ideological analysis may readily locate, precisely here, representations of those features rendered invisible by power and usage even as they dictate our lives" (Broderick, 1995:26). The machines possess aesthetic symmetry and appeal, but are simultaneously terrifying in their immensity and indifference to the humans who service them, thus encapsulating science fiction's typical ambivalence towards technological advancement. Bourbon (1999:190) trenchantly notes that "[i]t is the central fact of our modern existence, made explicit with evolutinary theory and the technological transformation marking our modern economies, that our finding and losing ourselves takes place in relation to science and technology". While mechanization ostensibly frees the proletariat, paradoxically they remain enslaved, for the machines cannot run themselves unsupervised. Rather, they need workers to tend their needs 24 hours a day. The machines thus become metaphors for the control exerted by the upper classes, who possess capital, over the deprived worker classes. The film portrays the city as requiring both exhausting physical labour (when Freder takes a worker's place at the clock

1 I am indebted to Ximena Gallardo (personal communication, 2002) for my discussion of the analogy between the Christian spaces of Heaven and Hell and the upper and lower levels of Metropolis. 
machine, he is completely drained by the exertion) and mechanical power. In this way, Lang emphasizes the iniquity of mechanization, which enslaves workers in the same way as manual labour does. As Marcuse (1964: 24) writes:

To Marx, the proletarian is primarily the manual laborer who expends and exhausts his physical energy in the work process, even if he works with machines. The purchase and use of this physical energy, under sub-human conditions, for the private appropriation of surplus value entailed the revolting inhuman aspects of exploitation; the Marxian notion denounces the physical pain and misery of labour. (My emphasis- DB.)

The machines resemble hostile faces, with a large mouth in the centre of their collective "face". When there is a mechanical breakdown as a result of one worker's exhaustion, Freder, who has strayed down to the machine level in pursuit of Maria, sees a vision of the machine as a colossal and insatiable mouth relentlessly swallowing workers. The vision fades as Freder regains his usual faculties, but the film does not invalidate it in any way. Indeed, this image is a filmic concretization of Marx's understanding of capitalist-industrialist society, swallowing and destroying workers' energies in the devouring pursuit of its own profit. There are also religious overtones in the similarity between the machine's "mouth" and the God of Mammon, who devours his own worshippers. The lowest level of the city, predictably, is the Workers' City, imaged as a collection of tenements, with grimy children running about in corridors and fleeing like rats from the flood that is caused when the workers sabotage the machine. This level, visually removed and hidden from the capitalists' domain, represents the "social/political unconscious" (to adapt Fredric Jameson's term) as it is denied in the capitalists' thinking about their own space.

In Jameson's (1975) ${ }^{2}$ words, much science fiction uses the device of "world-reduction" in its portrayal of alternate worlds. This strategy is evident in Metropolis, where only those parts of the city that are significant for the class struggle are shown explicitly. Thus, there is no image of the diverse zones that a real city would contain, such as an industrial area, low, middle and high-class residential areas and a

2 I am referring here to Jameson's article, "World-reduction in Le Guin: the emergence of utopian narrative" (1975), where Jameson discusses Le Guin's strategy of placing her characters in extreme situations in order to explore their psychological landscapes. 
commuter's zone. ${ }^{3}$ The only areas that are portrayed are the central business district, from which the city's economic masters wield their power; the recreational areas where, the film implies, the bourgeoisie indulge their sexual and competitive vices; the machine level; and the workers' tenements. Besides being a prerequisite for economically viable film-making, which tends to represent only selected aspects of any environment, this strategy reinforces the capitalists' denial of, first, the social diversity of their urban environment4; and, second, their dependency on the workers' labour.

\section{The plight of the workers}

In their use of vertical metaphors to indicate class division, Lang and Moroder draw strongly on Marx's class analysis, with the propertyowning bourgeoisie at the top of the economic hierarchy, managers in the middle and workers at the bottom of the financial scale. There are some departures from a classical Marxist analysis, especially in the workers' tenements, which are more reminiscent of low-cost project housing in the U.S. than of the disorganized and thoroughly horizontal workers' squatter camps in Victorian cities. La Gory and Pipkin (1981: 69) describe the latter as follows:

[During the era of industrialization] [l]arge numbers of working-class families were housed in northern England in terraced cottages. The extreme poverty and desolation of these grimy communities is well known. Lewis Mumford (1961) speaks critically of these settlements as 'coketown', 'mechanicville', and 'manheap'.

The use of tenements rather than a sprawling slum to represent the workers' housing is in keeping with the limited subterranean space available. It also stresses a feature that is introduced earlier in the film, namely the workers' anonymity. In the scene entitled "The shift change", as the workers enter the machines' domain, they are imaged as a mass of indistinguishable cyphers, all clad in identical uniforms and all identically downcast. 5 The repetitiveness and the mass-production of

3 My list of zones is derived from La Gory and Pipkin (1981:91), who give a brief list of some of the zones that are recognized by urban analysts in their construction of models of urban organization.

$4 \quad$ La Gory and Pipkin (1981:238) are not the only theorists to define cities as "mosaic[s] of social worlds, ... area[s] of great diversity".

5 Erica Hawkins (2001) writes in her online review of the film: "The monotonous droves of workers are truly a 'mass of men leading lives of quiet desperation', to quote Thoreau". 
human beings in this visual image defamiliarizes the "usual" filmic representation of characters, provoking, according to Mather (2002:88) an effect of alienation that is characteristic of science-fiction film. The film's use of defamiliarization, or alienation, coincides serendipitously with Marx's discussion of "alienation" amongst workers (which I discuss below) as a result of their oppression by the moneyed classes.

The workers are identified only by numbers, which erase their individuality, and only when Freder follows them to a subversive meeting with Maria does he learn to distinguish one from another. In a similar vein, tenement housing, with its interchangeable tiny living spaces, diminishes the uniqueness of individual workers and their families. In addition, the construction of tenements implies capital investment, thus pointing to conscious, but not benevolent planning by the "masters of Metropolis," who clearly stand to benefit by cramming as many workers as possible into tiny living spaces.

Predictably, the only level where any form of natural life (plants and animals) exists is in above-ground Metropolis. The "circus" arena where Freder and his peers compete for manly dominance through physical prowess is adorned by plants, while the Garden of Earthly Delights is a real garden, laid out in accordance with an intention to dominate natural phenomena and create a pleasing venue for the sexual diversions it offers. Its artificiality and the superficiality of the sexual play it houses are exposed when an enormous door opens and Maria enters surrounded by a crowd of children, whom she tells naïvely (but with palpable irony on the director's part): "Look, children, these are our brothers and sisters". The fact that the garden is walled in creates a boundary between its denizens and the "social Alien" (Le Guin, 1992:94).

Le Guin (1992:93-94) writes sceptically about the portrayal of workers in contemporary science fiction:

... how about the social Alien in SF? How about, in Marxist terms, 'the proletariat'? Where are they in SF? Where are the poor, the people who work hard and go to bed hungry? Are they ever persons, in SF? No. They appear as vast anonymous masses fleeing from giant slime-globules from the Chicago sewers, or dying off by the billion from pollution or radiation, or as faceless armies being led to battle by generals and statesmen ...

The people, in SF, are not people. They are masses, existing for one purpose: to be led by their superiors.

Le Guin's criticism of science-fictional representations of workers as faceless hordes applies perfectly to Metropolis. This train of thought 
leads her to the obvious conclusion that "From a social point of view most SF has been incredibly regressive and unimaginative" (Le Guin, 1992:94). I suggest, however, that the proletariat in Metropolis are imaged as faceless not because of the directors' political conservatism, but because that is how their exploiters view them: they are all identical and all expendable.

As a product of his class, Freder is ignorant of the workers' plight until his journey below the ground: one of the ideological mechanisms buttressing the capitalists' exploitation of the workers is their own denial of the relations of production that keep the city functioning. A crucial part of this denial hinges around "not letting the children know", as a result of which Freder attains adulthood completely unaware of his father's oppression of the workers. In Metropolis, as in Marx's analysis of capitalist society, the bourgeois classes, who possess capital, maintain their lifestyle by exploiting the labour classes and then denying their dependency on them. This denial is epitomized in the confrontation between Freder and his father. Freder asks why the capitalists treat the workers so badly. He protests, "But it was their [the workers'] hands that built Metropolis!" Fredersen does not reply, because his guilt is undeniable; nevertheless, he clings to the false consciousness that tells him he is entitled to exploit human beings for his own gain.

Marx and Engels (1935:12 write in The communist manifesto that:

The history of all hitherto existing society is the history of class struggles. Freeman and slave, patrician and plebeian, lord and serf, guildmaster and journeyman, in a word, oppressor and oppressed, stood in constant opposition to one another, carried on an uninterrupted ... fight that each time ended either in a revolutionary reconstitution of society at large or in the common ruin of the contending classes.

This conflict is vividly portrayed on film in Metropolis. The spatial separation between the haves and the have-nots, where the capitalists live in orderly and luxurious spaces above ground and the workers eke out a pitiful existence in subterranean tenements, indicates their differing interests and the inevitable conflict between them. Simply expressed, the capitalists want the workers to expend their energies in maintaining their lifestyles at the lowest possible wages, while the workers want (and deserve) a decent wage and better working conditions, as well as access to the city's resources so that they can pursue their own interests. Significantly, there are no images of money in the film - the economic dimension is implied rather than imaged directly. The capitalists' power is shown, instead, as domination, exploitation and mistreatment of the 
workers. Between the two there is an immutable gulf of interests, which is bridged by the two Marias and finally by Freder.

\section{The function of spatial images}

The film's vertical spatial images function on a number of semantic levels. Where above-ground urban space is concerned, they represent an impulse towards transcendence of natural and of human limitations, which is seen in the architecture of skyscrapers and impressive religious buildings in many societies and cities. The depiction of interior space as orderly, generous and uncluttered serves in a similar way to create an urban environment that is clean and orderly. Underground, the realm of the machines is also organized around vertical axes. The workers enter the factory by means of giant lifts that convey them either up or down, towards the machines or away from them. The machines comprise many levels, with the top levers seeming to chew like giant teeth. The interior space is designed in accordance with the scale of the machinery. Once inside the huge device, the uniformed and numbered workers apparently turn into machine parts themselves, moving with metronomic precision as they service their mechanical masters.

Taken in all, these three levels spatialize the class division that is apparent in the urban whole called Metropolis. Only the property-owners and those who are at the top of the economic hierarchy have the means and the right to dispose of space and to inhabit it in generous measure. The implication is, as in Marx's analysis, that the workers are far more numerous than their bosses and yet are powerfully oppressed and exploited, to the extent that their very identity has been stripped from them, leaving them only with numbers. They are, in Marx's vocabulary, intensely alienated from their own labour, as they are not deriving any material benefit from it. Marx describes the condition of economic alienation as follows:

... the work is external to the worker, that it is not part of his nature; and that, consequently, he does not fulfil himself in his work but denies himself, has a feeling of misery rather than well being, does not develop freely his mental and physical energies but is physically exhausted and mentally debased ... It is not the satisfaction of a need, but only a means for satisfying other needs ... Finally, the external character of work for the worker is shown by the fact that it is not his own work but work for someone else, that in work he does not belong to himself but to another person (cited in Fromm, 1961: 98-99).

As a result of their alienated labour, the workers are also alienated from the spaces they inhabit and where they work. The hostility of the 
machines towards human life is palpable and does not need Freder's vision of a gaping maw to confirm it. But the machines themselves, like Rotwang's malevolent invention of the false Maria, are human constructs and embody only the values that their makers have invested in them. The underground machine is the capitalists' servant and its appetite for human flesh is analogous to the capitalists' greed for profit and physical indulgence. The corollary to the workers' alienation from their spaces is that the owners themselves are also alienated from their city, since they symbolically erase and immiserate the workers who provided the force to construct their own urban space. I read the "birds'-eye view of the city", with its raised highways and skyscrapers, not only as a symbol of transcendence, but also a sign of the capitalists' false consciousness: their denial of the conflict with the workers.

\section{Gender in Metropolis}

The film's gender dimension is startling, since it contains only one rounded woman character, namely the workers' leader and the eventual mediator of the conflict between the workers and the capitalists: Maria. (Here I diverge dramatically from Marx's analysis, which did not include gender or sexuality.) She is split into two figures - a real Maria and a "false" one. The false Maria, who bears false consciousness to the workers is a robot impersonation of the real woman. Jane Donawerth $(1995: 210)$ describes the representation of women as machines in science fiction as follows:

In our society, and in traditional science fiction by men, science and technology have been male territory, and the machine has been seen as male. When a woman is represented as a machine by male writers, she is almost always presented as a sex toy ...; man's superiority is indicated by his link to science, while woman's inferiority is represented by her connection to the mechanical body.

In keeping with Donawerth's analysis, the robot Maria is indeed created by a male scientist (albeit an insane one) and used by men for sexual purposes. She mesmerizes the workers and the moneyed classes alike by flaunting her body, as is apparent from her very first entrance and meeting with Joh Fredersen. Her message to the labourers is violent revolt against their oppressors, which sounds liberating, but is a cunning trap set by the capitalists as she lures them, through her sex appeal, to sabotage the machines and endanger their own homes.

In another aspect of the film's Christian symbolism, the real Maria unmistakably echoes the mother of Christ (as her name indicates). She holds meetings in an underground crypt adorned with crosses and styles 
herself as an apostle of love, trying to explain the workers' situation to them and telling them to put their faith in an as-yet-unrevealed mediator between themselves and their enemies. In Marx's view, the real Maria's message would be an example of false consciousness - a diversion of the proletariat from the reality of their situation. To a certain extent, this appears to be the case. Maria embodies some attributes of a stereotypically feminine role, namely that of a mother. Her physical postures and movements (for example, stretching her arms out to the workers, promising a nurturing embrace), her dress and tone of voice, all bespeak a mother's care, especially in the scene where she and the children in her care interrupt a prostitute's seduction of Freder in the Garden of Earthly Delights. In a gendered role-distribution that may have escaped Marx's notice, all the workers in Metropolis are men; and it seems likely that Maria's implicit and explicit offer of maternal nurturing would draw their attention away from the vicious class struggle they are embroiled in.

Yet a number of elements militate against a simplistic interpretation of Maria as an enemy of the workers' struggle. First, Maria is clearly an activist. It is she, not the workers, who calls meetings and preaches a subversive message, as seen in her parable of the rich man and the tower of Babel. She encourages the workers to think about their relationship with their exploiters and to realize that they are being mistreated. In this respect she aligns herself with the class struggle, even if her contribution is merely ideological and consciousness-raising and does not extend to the active promotion of a workers' revolution.

The false Maria, created by the insane scientist Rotwang, embodies strikingly different qualities from her real counterpart. Created in the image of both the real Maria and Rotwang's lost love, Hel (Joh Fredersen's now-dead wife), she epitomizes the dangerous allure of sex as distraction for both the capitalist and the worker classes from their real conflict and the need to alter existing relations of production. Her first action is to wink seductively at Joh Fredersen and to rub her skirt provocatively - an act that is not lost on Fredersen, who knows her artificial nature. Outside Rotwang's laboratory, she becomes a sexual magnet that draws the capitalists and the workers alike. In Yoshiwara's, she performs a frenzied dance, evidently beguiling the energies of bourgeois men. But her influence on the workers is yet more dangerous, for she masquerades as the inspiration and leader of their revolt against their masters, only to lure them into a suicidal plan to destroy the machines, flood their own homes and nearly kill their own children. It is only the real Maria's intervention, aided by Freder, that halts the impending disaster. 
Significantly, in this episode the false Maria does not jettison her sexual appeal in assuming the role of the workers' leader. Sexuality is still present, but now she functions as a femme fatale or siren, leading them to their own destruction. They follow her because she is sexy: their own physical desires, starved of expression by the conditions of their labour, lead them into false consciousness - forgetting the true nature of their position and their dependency on the machines.

In both her incarnations, Maria embodies Joanna Russ's (1995:81) complaint against the stereotyping of women in literature (and, by extension, in films) authored by men:

Our literature is not about women. It is not about women and men equally. It is by and about men.

If you look at the plots [of male-authored literature] ... you will find not women but images of women: modest maidens, wicked temptresses, pretty schoolmarms, beautiful bitches, faithful wives, and so on ... at their best they are depictions of the social roles women are supposed to play and often do play ....

While the real Maria represents, on the one hand, a devoted and selfsacrificing mother, and, on the other, "the protagonist of a Love Story" (Russ, 1995:84), the false one represents "the wicked temptress". Splitting the film's only woman character into two stereotypes bespeaks a gender conservatism that is typical of, but not restricted to science fiction. In Metropolis, Maria's portrayal resonates with danger: while she embodies sexual attractiveness, she distracts the workers from the class struggle and the necessity of revolution.

\section{Conclusion}

The combination of spatial and gender elements in Metropolis makes for a complex depiction of class conflict in an economically stratified society. The political and economic gulf between the capitalists and the workers seems impossible to bridge. For this reason, the film's dénouement is, regrettably, not entirely convincing. In Marx's concept of history, there can be no resolution to the immutable conflict between exploiters and exploited (capitalists and workers). Rather, the process of dialectical materialism ensures that the conflict may end in revolution, but that a new class of exploiters will arise, and a fresh conflict begin. This seems more likely than the rather sentimental ending of Metropolis, which leaves many questions unanswered. For example, what will Joh Fredersen's relationship with the workers be after he has nearly lost his son in the subterranean disaster? Will Freder take over his father's role 
as master capitalist (a role for which his position as the only son seems to predestine him)? Or will he renounce his wealth and join the workers, sharing the abject squalor of their living conditions? The film implies that Joh Fredersen will have a change of heart and begin paying his workers a decent wage so that they can live more comfortably, but this is not guaranteed.

Metropolis, in both its original and late twentieth-century versions, deploys the science-fiction genre to outstanding effect. It creates a visually stunning and yet credible portrait of an ideal city, in Tuan's terms: "The city liberates its citizens from the need for incessant toil to maintain their bodies and from the feeling of impotence before nature's vagaries" (1974:150). Elsewhere Tuan (1974:152) states: "The [ideal] city transcends the uncertainties of life; it reflects the precision, the order, and the predictability of the heavens". The radial symmetry of Metropolis's layout, its machine-like precision (the city's buildings, roads and walkways all interlock like the parts of a clock), its clinical cleanliness and its evident artificiality all make it a triumph on the part of capital. But economically and spatially underlying this achievement is the exploitation and immiseration of thousands of workers, whose alienated labour services and maintains the city and ensures the continued provision of its resources to the economically privileged few. In Metropolis, Fritz Lang implies that an utopia that is founded on exploitation and suffering is closer to dystopia than utopia. As Le Guin (1992:151) reminds us, "Science fiction is not predictive; it is descriptive". The apparently fantastic, extrapolative buildings and machines that make up the urban environment of Metropolis provide the directors with a framework in which to explore the far less fantastical conditions of class and labour conflicts. By drawing on Marx's analysis of class and labour relations, Metropolis offers a filmic concretization of the conflicts that attend a politically and economically stratified urban environment, as well as a possibly reluctant depiction of the role of women in a workers' struggle.

\section{Bibliography}

Bourbon, Brett. 1999. Is science fiction a who or a what? Extrapolation, 40(3):189199.

Broderick, Damien. 1995. Reading by starlight: postmodern science fiction. London/ New York : Routledge.

Donawerth, Jane. 1995. Woman as machine in science fiction by women. Extrapolation, 36(3):210-221.

Fromm, Erich. 1961. Marx's concept of man: with a translation from Marx's 'Economic and philosophical manuscripts' by T.B. Bottomore. New York : Ungar. 
Hawkins, Erica. 2001. Fritz Lang and Metropolis: the first science fiction film. Available on internet: http://www.persocom.com.br/brasilia/erika.htm (December 2001). (Date of access: 10 January 2002.)

Hume, Kathryn. 1984. Fantasy and mimesis: Responses to reality in Western literature. New York : Methuen.

Jameson, Fredric. 1981. The political unconscious: narrative as a socially symbolic act. London : Methuen.

Jameson, Fredric. 1975. World-reduction in Le Guin: the emergence of utopian narrative. Science Fiction Studies, 2:221-230.

La Gory, Mark \& John Pipkin. 1981. Urban social space. Belmont, California : Wadsworth.

Le Guin, Ursula K. 1992. The language of the night: essays on fantasy and science fiction. Revised and with a new introduction. New York : HarperCollins.

Marcuse, Herbert. 1964. One-dimensional man: studies in the ideology of advanced industrial society. Boston : Beacon.

Marx, K. \& Engels, F. 1935. The communist manifesto. New York : International Publishers.

Mather, Philippe. 2002. Figures of estrangement in science fiction film. Science Fiction Studies, 29:186-201.

Moroder, Giorgio. 1984. Metropolis (film). Originally directed by Fritz Lang, 1926.

Mumford, Lewis. 1961. The city in history: its origins, its transformations, and its prospects. London : Secker \& Warburg.

Russ, Joanna. 1995. To write like a woman: essays in feminism and science fiction. Bloomington/Indianapolis: Indiana University Press.

Suvin, Darko. 1979. Metamorphoses of science fiction: on the poetics and history of a literary genre. New Haven/London : Yale University Press.

Tuan, Yi-Fu. 1974. Topophilia: a study of environmental perception, attitudes, and values. Englewood Cliffs, N.J. : Prentice-Hall.

\section{Key concepts:}

gender in science fiction

Marxist class analysis

Metropolis (Lang; Moroder)

science-fiction film

urban space

\section{Kernbegrippe:}

gender in wetenskapsfiksie

Marxistiese analise van klas

Metropolis (Lang; Moroder)

stedelike ruimte

wetenskapsfiksie 